\title{
DIALECT IN INTERACTION BETWEEN SELLERS AND BUYERS AT PASAR RAME MEDAN
}

\author{
*Melina Putri \\ **AmrinSaragih \\ **AnniHolilaPulungan
}

\begin{abstract}
The research was focused on the topic about Dialect caused by in Interaction between Sellers and Buyers at Pasar Rame Medan. This study was aimed at identify the dominantly types dialectcaused by and realize the dialect that used in interaction between sellers and buyers at Pasar Rame Medan. The source of data was taken from the conversation between sellers and buyers at Pasar Rame Medan that used dialect. The data were collected by using recording technique. Instrument for collecting the data is using tipe recording. The technique for analyzing the data is descriptive qualitative research. The result of this research was types of dialect caused by can be found are, Geographical (33,33\%), Socio-Economic Status (SES) (36,66\%), Age $(23,33 \%)$, and Sex $(6,66 \%)$.The most dominant type of dialect that used in interaction between sellers and buyers at Pasar Rame Medan is Socio-Economic Status with percentage $28.80 \%$. Realize of the dialect that found in interaction between sellers and buyers at Pasar Rame Medan were made possible by some factors: Phonology (pronounce, stress, tone and pitch), lexicon and grammatical aspects.
\end{abstract}

Keywords: Dialect, Phonology 


\section{CHAPTER 1}

\section{INTRODUCTION}

Indonesia is a country that rich of culture and languages which has linguistic diversity in every tribe. Here exist hundreds of ethnics, culture and local languages which besides here. Every region in Indonesia has its own local language. Every local language has its own dialect. Dialects itself is a part of language, which is spoken by a group of community and understood by others. Though in one regional, there are many dialects. Such as Medan country, have Bataknese dialect, Javanese dialect, Padangnese dialect, Mandailingnese daielct and etc. Despite of the differences, Indonesian people live together in harmony. Language is a form of identity for the people. When a person use language, other people will be able to mark certain characteristics from the way that person use the language. Those characteristics will then used to identify the person, such as dialects of certain ethnic, or the way someone use language. Using the right language in the right situation without breaking people heart can show that we have a good identity. Also, by using the right language in the right condition, we will be able to convey our intended message to other people properly. Because of this, the study of language is very important. Sizu (2014:2) states that, dialect is a varieties of language used recognizably in a specific region or by a specific social class. 
All aspects of human life can't be separated from the use of language as a means of communication. Included in the market, here we will find many kinds of language used by dialect that is different from each other. In the market also we will make the interaction between sellers and buyers who want to buy and sell goods and services are sold.

In social life, each individual is bound by race, ethnicity, culture, and particular atmosphere. Each community that uses a different language giving rise to a form of dialect different which become identity of the speakers, Sudono (2014:37). In the society, dialect from the immigrant people is disappearing, because it influence by the people that must follow the situation and condition where they was. Mostly, the younger human feel not comfortable or feel embracing to show their identity by dialect.

These phenomena that make the researcher interested to analyze about this topic. Because in the theory based on Asanosi (2014), states that dialect is the identity of the speakers but in the reality, which is still so many people actually younger people feel not comfortable to show their dialect that show their identity to the society.

Based on Saragih (2016), states that dialect is one of the varieties of language that caused by user. It means that dialect is user. In his book, there are fourth types of dialect that caused by Geographical origin, SocioEconomic Status (SES), Age, and Sex. Geographical origin is dialect that used 
in one regional places or geographical area spoken, for example in West Java specifically in Lembang, people used sundanese dialect in their places. It is according to the geographical area. Socio-Economic Status (SES), this dialect that used by people belonging to particular social classes, groups, religion ethnicity and status. For example, for the higher and lower social classes have

a different dialect each other. Age, this varieties of language, dialect that used by the age of individual speakers, for example, language of children, language of teenagers and language of adult certainly have a different dailect. Sex, this is the varieties of language that seen by the gender speakers, for example language that used by man and women.

The researcher interested to analyze dialect caused by that used in interaction between sellers and buyers at Pasar Rame Medan. The purpose of this thesis is to analyze the types of dialect caused by that dominantly found and to show how is the realized of dialect caused by that found in interaction between sellers and buyers at Pasar Rame Medan.

\section{REVIEW OF LITERATURE}

Based on Georgieva (2014:4), sociolinguistics is concerned with investigating the relationships between language and society with the goal to understand more thoroughly the structure of language and how languages function in communication. Sociolinguistics explores language in relation to 
society. So it is concerned with language as used for communication amongst different social groups of people in different social situations or culture.Based on Holmes (2001:1) Sociolinguistics is study the relationships between language and society. They are interested in explaining why we speak differently in different social contexts, and they are concerned with identifying the social function of language and the ways it is used to convey social meaning.From the expert point of view, the researcher get the point that sociolinguistic is applied of linguistic that study about language and how language used in the society.

Another dimension for languages diversity which is influenced by different ethnic or culture which is dialect used.Sizu (2014:2) states that, dialect is a varieties of language used recognizably in a specific region or by a specific social class. The term dialect is used in two distinct ways, even by linguists. First, refers to a variety of language that is acharacteristics of a particular group of the language's speakers. The term is applied most often to regional speech patterns, but a dialect may also be defined by other factors, such as social class. Second, refers to a language that is socially cognate to the standard to a regional or national standard language, often historically cognate to the standard, but not a variety of it or in any other sense derived from it.

So, a dialect is a type of language spoken by a group of people. Sometimes people who live in the same place make a dialect. Sometimes 
people who are similar in some way make a dialect. There is no agreed difference between a dialect and a language. Other dialects are different types of a language that come from different places or countries, Sizu (2014:2).

Based on Assanosi (2014:4), dialect is different from language and Accent in this way. Language is group of linguistic norms and dialect with special grammar, pronunciation and vocabulary. Dialect is a dialect is a variety of language, spoken in one part of a country or by people belonging to a particular social class. Accent is variety of pronunciation of the same words. Based on Saragih (2016), he said that dialect is one of the varieties of language that caused by user. It means that dialect is user. In his book, there are fourth types of dialect that caused by Geographical origin, SocioEconomic Status (SES), Age, and Sex. Wardhaugh (2016) states that dialect has became the identity marking. Identity marking is a speaker may use dialect to signal a type of identity.

\section{RESEARCH METHODOLOGY}

\section{Methodology}

This research will be conducted by using descriptive qualitative research. This research will be conducted by using descriptive qualitative method, descriptive derived from two words, they are descriptive and qualitative. Descriptive is something which described. Descriptive study is a way where the information collected without changing the environment and 
often call as the observational studies. In supporting the statement, Best and Kahn (2002) define that a descriptive study describes and interprets what is concerned with conditions or relationship that existed, opinions that are held, processes that were going on, effects that were evident, or trends that are developing and occurred in current conditions. Besides, qualitative study is in terms of using words. Best and Kahn (2002) also state that the qualitative study is something in which the description of observations is not ordinarily expressed in quantitative terms.

\section{Data Analysis}

In analyzing the data the researcher used theory proposed by Miles and Huberman (2014), said that the qualitative data analysis consists of three procedures. They are Data Collection, Data Reduction, Data Display and Drawing and Verifying Conclusion. In the conducting research, the researcher selected data that will give valuable information in research: the data was chosen by identifying and classifying the types of dialect caused by. In displaying data, the researcher described data by tabulating the types of sound devices into a table (Appendix A). And calculate those data by using a formula to show the dominant types of dialect caused by. The last step after doing the data display is drawn of the conclusion and verification. It made an interpretation based on the finding from the data sheet. The result was the limited interpretation by the writer herself. It wasused to describe all of the data so that it would become clearly. 


\section{DATA ANALYSIS AND RESEARCH FINDINGS}

The dialectis showed the 4 types of dialect caused by were found in the following utterances and the analyze dialect caused by of Geographical Origin, SocioEconomic Status, Age and Sex dialect in every conversation.

\section{The Dominant Types of Dialect caused by that found in Interaction between Sellers and Buyers at Pasar Rame Medan}

Theoritacally, there are four types of dialects that caused by Geogphical Origin, Socio- Economic Status, Age, and Sex. This part is found the dominant types of dialect that used in interaction between buyers and sellers at Pasar Rame Medan.

Table 4.1

The Precentage of Dialect

\begin{tabular}{rlll}
\hline No. & Types of Dialect & Total & Precentage $(\%)$ \\
\hline 1. & Geographical Origin & 10 & 33.33 \\
\hline 2. & $\begin{array}{l}\text { Socio-Economic Status } \\
(\text { SES })\end{array}$ & 11 & 36,66 \\
\hline 3. & Age & 7 & 23,33 \\
\hline 4. & Sex & 2 & 6.66 \\
\hline Total & & 30 & 100 \\
\hline
\end{tabular}

The dominant types that found are Socio-Economic Status with a precentage $33,33 \%$, then Geogrphical-origin with a precentage 36,66\%, after that Age with a precentage $23,33 \%$ and the last are Sex with a precentage $6,66 \%$. In summary, $100 \%$ 
of dialects are used in the interaction between buyers and sellers at Pasar Rame Medan.

The precentage of dialect on Socio-Economic Status is the highest with 11 $(36,66 \%)$ dialect focuses. It is becaused in the traditional market, all people by different background, ethnicity, social, economic, and status can meet to do transactional activity. On the type dialect of Geographical-origin with $10(33,33 \%)$ dialect focuses were caused by North Sumatera especially Medan, are majority Bataknese dialect that can easier to see when they pronounce. It's especially in Pasar Rame traditional Market, the buyers and sellers are dominant Bataknese people and Chinese people. And also, Geographical-Origin can't seperated with caused SocioEconomic Status. For example, bataknense people used bataknese dialect with a strong and harsh intonation, but by a higher education background of the speakers, they can choosen the grammatical word that polite to the other and just the apposite. On the type dialect that caused by Age with 7 (23,33\%) dialect focuses. It is because the interaction between buyers and sellers that happend at Pasar Rame Medan it's difficult see their age by their used of language. And the lowest type of dialect Sex with $2(6,66 \%)$ dialect focuses. It is because in the Pasar Rame Medan, one of traditional market at Medan, the researcher so rare meet with the buyers and sellers with different gender. Mostly, buyers and sellers are women from all age from different background. 
Based on theory from Saragih $(2016: 167)$, there are fourth types dialect that caused by. Here, based on the data, the researcher found the dominant type of dialect caused by is Socio Economic Status. Socio Economic Status is Varieties of a language used by people belonging to particular social classes and social dialects originate among social groups, and are related to a variety of factors, the principal ones apparently being social class, religion, status and ethnicity.

The italic ones marked the time when certain dialects of Socio-Economic Status were used in interaction between buyers and sellers at Pasar Rame Medan.

\section{Conversation 8}

Seller : entar dulu kak 'wait a minute sis'

Buyer : kauambil yang besaraja, disini kotaroknantilubangnya yah, ehbilangin napa tawar (bicara sama temannya).

'You should just take the bigger one, put the hole in here okay, hey please bargain the price (talk to her friend)

From the dialogue above, it can be seen that the buyer and seller are used Bataknese pronounce in their conversation as the signed. The sellers and buyers choosen the grammatical word which is usually used by Bataknese people with a strong intonation of the word 'entar' (wait), 'kau' (you), 'kotarok' (put the). And also the sellers and buyers in this interaction are showed Social-Economic Status, which contained of the bacground from the buyers that didn't choosen soft word to the sellers. It can be seen by the stress and tone (suprasegmental) that used of the 
sellersand buyers. The pronounce of the buyers when speaks like anger to the sellers, its not polite language showed her background of social status.

\section{Conversation13}

Buyer :dekakujugakjual di pajaksimpanglimundek, iniambekdua. 'dek, I'm also a seller in simpang limun traditional market, dek.

Here, I'll take two'.

Seller : iya, udahmurahinibuk. 'Yes, ma'am. The price is already too cheap'.

Buyer : iniseratuslah, yang itusatudua. 'I'll take this for one hundred (thousand rupiah), and that one for one-two (one hundred twenty thousand rupiah)'.

Seller : itugakdapat. 'i can't give you that price'.

From the dialogue above, it can be seen that the sellers and buyers are used Bataknese dialect that showed by the buyers in the word 'dek, aku jugak' 'ambek', her pronounce when speak the word are dominant of Bataknese dialect. And also, from the background her occupation that she was said in the conversation 'Dek aku jugak jual di pajaksimpanglimundek', it explain her Social Status by the occupation. Because her occupation in the tradional market too. And also by the stress and tone that the buyers used it can been seen that the sellers also used dialect bataknese.

\section{Conversation9}

Buyer : pasnyaberapaih? 'What is the exact price, ih?'

Seller : anamtiga. 'six hundred thousand rupiah'

Buyer : gakbisa lima setengah?. 'Can you cut it down to five hundred and half?'.

Seller : gakkuranglagibuk, ini yang las, kalok yang medium bisa. Ini yang las yang medium bisa.Initulisanlasbuk, lasmaksudnyatinggi, 
kokmedium setengah, lacinyagitupendek, laenbuklassama medium. I can't make the price any cheaper. This is las, if you asked the medium one I can give a discount, but this is las. Can't you see the writing, ma'am? It'slas. Las is of a higher quality, the medium one is standard quality, the drawer is short. Las and medium are differenrt, ma'am'.

From the dialogue above, it can be seen that the sellers and buyers used Social Economic Status are dominant in this conversation. The sellers and explain by the word with detail to the buyer 'gakkuranglagibuk, ini yang las, kalok yang medium bisa. Ini yang las yang medium bisa.Ini tulisanlasbuk, lasmaksudnyatinggi, kok medium setengah, lacinyagitupendek,

laenbuklassama medium'. It showed that the sellers have a good background that can be seen by a choosen of the word that the the sellers used. The buyers also have a good background that can be seen by her pronounce that really soft (stress) pronounce when making interaction. And also the sellers which is from chinese people that really strong of pronounce (stress and tone) hokkian dialect. In the conversation can be seen that the sellers are explain by a strong intonation like anger, but the buyers doesn't influenced to reply with anger intonation too, by stress and tone. When the buyers can't buy her things, the sellers also didn't angry with the buyer.

\section{Conversation11}

Seller : kalo saran akusihlebihbagusbesarsikittapilebihnyaman. 'If I can suggest you sih, the bigger the better, it will be more comfortable'.

Buyer : iniberapakak? 'How much is this, sis?'. 
Seller : iniseratusdelapanlimaaja bisa kurang. 'you can have this for one hundred eighty five, I'll give some discounts'.

Buyer : kalomodel pingganggakadakak? 'Do you have the waist-style, sis?'.

From the dialogue above, it can be seen that the sellers and buyers used same dialect caused by social economic status, because the sellers and buyers make their interaction are so friendly each other. The conversation shows that their same status as a younger are influenced the choosen of the word that used.

\section{Realization of Dialects in Interaction between Buyers and Sellers at}

\section{Pasar Rame Medan}

\section{Bataknese Dialect}

\section{Conversation8}

Sellers : entar dulu kak. 'wait a minute, sis'.

Buyer : kau ambil yang besar aja, disini ko tarok lobangnya yah, giniyah. 'you should just take the bigger one, put the hole in here, okay'

From the dialogue above, it can be seen that the buyer and seller dominantly used Bataknese dialect from the way they convey their conversation. The buyer used a kind of rude 'you' (kau), 'wait' (entar) and 'put the' (ko tarok) which is usually used by Bataknese. The buyer also used a strong intonation which is very typical of Bataknese. Aside from that, the trace of Bataknese dialect can be heard in the pronunciation. In here the sellers used a strong intonation like a mostly. The sellers are the man that has thick of stress. And 
also the sellers and buyers in this interaction are showed Social-Economic Status, which contained of the bacground from the buyers that didn't choosen soft word to the sellers. The pronounce of the buyers when speaks like anger to the sellers, its not polite language showed her background of social status. It shows that the identity of the buyers are bataknese people. In other side, the sellers are like a pople in the market mostly, it shows his identity as the sellers in traditional market. Their identity can seen by the seller and buyers used stress and tone in their pronounce.

\section{Hokkian Dialect}

\section{Conversation19}

Buyer :iniberepong?'how much is this?'

Seller :ituduautas, duapelonglah. 'this is two hundred thousand rupiah' Buyer :kokmehong kali? 'really, why so expensive?'

Seller :hihihiiyaloh. 'hihii yes'

From the dialogue above, it can be seen that the both the seller and the buyer were speaking in a modern (gaul or trendy) dialect. This is especially apparent in the choice of lexical items, for example the use of words berepong, duautas, duapelong, mehong, which is commonly used by teenagers as a slang. The sellers and buyers are so closed seen by their conversation. The sellers in here used Hokkian dialect that shows their identity of the younger and gaul (modern) people in nowdays because of their same background of the Age. 
Their identity can seen by the seller and buyers used stress and tone in their pronounce.

\section{Javanense Dialect}

\section{Conversation11}

Seller : kalok saran akusih, lebih bagus besar sedikit, tapi lebih nyaman kak. 'if i can suggest you sih, the bigger the better, it will be more comfortable'.

Buyer : ini berapa kak? 'how much is this, sis?'

Seller : ini satu lapan lima aja bisa kurang. 'you can have this for one hundred eighty five, I'll give some discounts'.

Buyer : kalo model pinggang ada kak? 'do you have the waist-style, sis?'

The conversation showed that the buyer speak in a modern dialect. This is especially apparent in the choice of lexical items, for example the use of sih which is commonly used by teenagers. In here, the buyers and sellers show their identity as the the younger generation that used Javanese dialect. The way she speaks was also refined and gentle. The buyer and sellers in here used same Javanese dialect that heard so softly. It also showed the type of Age dialect in their conversation because the sellers and buyers make their interaction are so friendly each other. The conversation shows that their age with a same a younger are influenced the choosen of the word that used. 


\section{Padangnese Dialect}

\section{Conversation4}

Seller : hah, inilah nomor sapuluah no dua belas. 'hah this is it, this one isten size, twelve size. Hah, this is the pants, miss'.

Buyer : berapa itu? 'how much is it?'

Seller : udah tigo lima aja buk. 'for you I'll give 35 (thirty five hundred rupiah)'

from the dialouge between the seller and buyer above, it can be seen that the seller's (man) pronunciation are more heavy with Padangnese dialect and by the intonation was very strong, indicating power and dominance. As for the buyer (woman), the way she speak was more gentle and subtle. A man used stress of the word 'Hah inilahnomorsapuluah (10), nomor dua belas (12). Hah', that shows the man stress so distinct. So it show that their identity by the conversation include sex dialect between different gender. Their identity can seen by the seller and buyers used stress and tone in their pronounce.

\section{CONCLUSIONS AND SUGGESTIONS}

\section{Conclusion}

After analyzing all of the data for the types of dialects by the sellers and the buyers in Pasar Rame traditional market Medan, there were two research findings found based on the problems of the study. The research findings were presented as follows : 
1. All of the type of dialects caused by in interaction sellers and buyers, the total number of dialects in the conversations were 30 . There were 33.33\% conversation consist of dialect Geographical Origin, $36.66 \%$ conversation consist of dialect Socio-Economic Status (SES), 23,33\% conversation consist of Age, 6,66\% conversation that caused by Sex. The dominant types of dialect that used in interaction between buyers and sellers at Pasar Rame Medan are Socio-Economic Status. And also Geogrphicalorigin and Socio-Economic Status are related each other as the dialect that used in tradional market of Pasar Rame Medan

2. The findings showed that the realized of dialects are shows identity between buyers and sellers at Pasar Rame Medan. The realization of dialectsgeographical origin are show their identity based on ethnicity between buyers and sellers used dialect at Pasar Rame Medan. The realized dialect that found in interaction between buyersa nd sellers that found in Pasar Rame Medan are the sellers and buyers that used Bataknese dialect, Hokkian dialect, Javanese dialect and Padangnese dialect. The dialect realized can be seen by some factors: phonology, and lexicon items. Here, the researcher can be seen all of the identity of the sellers and buyers by their pronounce (tone, stress, and intonation). 


\section{Suggestion}

Having conducted a research about Dialect, it is useful to consider the following suggestions:

1. Despite the varieties of dialects, it is suggested for every citizens to keep being polite all the time. Any dialects can be used as long as politeness strategy is still applied.

2. The dialects used in traditional market are very diverse thus sometimes it is hard to understand some of it. To avoid misunderstanding, clarifying the intended meaning is greatly advised. 


\section{REFERENCES}

Adi, Azwardi. 2014. DialekBahas Aceh. Available online :was accsessed on 28 February 2017

Assanosi. 2014. Regional and Social Dialect. The Journal of Higher Education Vol. 53. No 7. The Ohio State University.

Carbonell, Delvin. 2016. Are you Victim of Langauge Discrimination?Available online: was accsessed on 25 february 2017

Carolina. 2013. PerkembanganPusatPasar Medan Tahun 1970-2013. Thesis University of North Sumatera. Medan.

Crystal, David (2003), A Dictionary of Linguistics \& Phonetics, Blackwell

Daulay.Sibarani.Nadra.Sembiring. 2014.Mandailing Phonological Variation in Mandailing Natal.IOSR Journal of Humanities and Social Science (IOSR$J H S S$ ).Volume 19.Issue 11.Postgraduate School of Linguistic Departmen North Sumatera University. Indonesia.

Dunstan. 2015. Dialect and influences on the Academic experiences of College Students.The Journal of Higher Education.Vol. 86.No. 5.The Ohio State University

Eisenstei. 2014. Identifying Regional Dialects in Online Social Media. SAGE Journal International.

Georgieva. 2014. Introducing Sociolinguitics. KlimentOhridski University of Sovia. Bulgaria.

Hidayati. 2014. VariasiBahasaLisanPedagang Kaki Lima dalamLingkunganSosial di Alun-Alun Kapuas. Mini Research.Faculty of Languages and Arts of Pontianak.

Hoffmann. 2016. Four Positive Effects of a Salesperson's Regional Dialect in Services Selling. 460-474

Kroch, S. 2013. Toward a Theoryof SocialDialect Variation. Lang. Soc. 7, 17 36.Printed in Great Britain.Temple University, Philadelphia.

Martha. 2017. MacamMacamPembelidanPenjual.Article . Available online: was accsessed on 25 february 2017. 
Moekijat.2017. MacamMacamPembelidanPenjual.Article.

Nasucha, Yakubdkk. 2013. Bahasa Indonesia UntukPenulisanKaryaTulisIlmiah. Yogyakarta: Media Perkasa.

Novianti, Rini. 2016. InilahDailek/LogatKental, KhasdanUnik di Indonesia.

General lifestyle.https://www.bersosial.com/threads/inilah-dialek-logat-kental-khasdan-unik-di-indonesia.32518/ was accsessed on 28 february 2017

Saragih, Amrin. 2016. Discourse Analysis. Medan:UNIMED.

Sevinj, M. 2015. Socialand Regional Variations of English Language.Global Journal of HUMAN-SOCIAL SCIENCE.V. 15. Issue. 12. Version 1.0.OdlarYurdu University. Azerbaijan.

Sizu. 2014. Sociolinguistic-Language, Dialects, and Varieties. MakalahPekanbaru.

Sutrismi. 2014. The Use of Indonesian English Code Mixing in Social Media Networking ( Facebook) by Indonesian Youngsters. Publication Article.Teacher Training and Education Muhammadiyah University. Surakarta.

Thomas. 2016. Bahasa Hokkian. Available online :http://forumkristen.com/index.php?topic=60422.0 was accsessed on 3rd March 2017

ToveSkutnabb. 2012. Linguistic Diversity and Language Rights. ISBN-13: 978-184769-189-7. Cromwell Press Group. UK.

Zulyana. 2016. AnalisisPenggunaanSakarindanSiklamatpadaManisanBuah yangDiajakan di PasarRame Medan. FakultasKesehatan Masyarakat.USU. Medan.

Wardhaugh. 2006. An Introduction to Sociolinguistics. ISBN-13: 978-1-40513559-7. Fifth Edition. Blackwell Publication. 